\title{
EFEKTIVITAS RATIONAL EMOTIVE BEHAVIOUR THERAPY BERDASARKAN PROFILE MULTIMODAL THERAPY PADA KLIEN SKIZOFRENIA DENGAN MASALAH KEPERAWATAN PERILAKU KEKERASAN DAN HALUSINASI DI RUMAH SAKIT JIWA
}

\author{
Retno Yuli Hastuti ${ }^{*}$, Budi Anna Keliat ${ }^{2}$, Mustikasari² \\ 1. STIKes Muhammadiyah Klaten, Jawa Tengah 57419, Indonesia \\ 2. Program Studi Magister Fakultas Ilmu Keperawatan, Universitas Indonesia, Depok 16424, Indonesia \\ 3. Fakultas Ilmu Keperawatan Universitas Indonesia, Depok 16424, Indonesia \\ *Email: retno_yh@yahoo.co.id
}

\begin{abstract}
Abstrak
Penelitian ini bertujuan mengetahui efektivitas Rational Emotive Behavior Therapy (REBT) berdasarkan profile multimodal therapy terhadap kemampuan klien dan perubahan gejala perilaku kekerasan dan halusinasi di RS Jiwa. Desain penelitian quasi eksperimental dengan jumlah sampel 56 responden. Sebanyak 28 responden memiliki Profile Multimodal Therapy untuk mendapatkan REBT sebagai kelompok intervensi, 28 responden sebagai kelompok non intervensi. Hasil penelitian ditemukan penurunan gejala perilaku kekerasan dan halusinasi lebih besar daripada yang tidak mendapatkan REBT berdasarkan profile multimodal therapy $(\mathrm{p} \leq 0,05)$. Kemampuan kognitif, afektif dan perilaku klien yang mendapatkan REBT berdasarkan profile multimodal therapy meningkat secara bermakna $(\mathrm{p} \leq 0,05)$ Hasil penelitian ini efektif meningkatkan kemampuan klien kognitif, afektif dan perilaku hingga 57\% dan penurunan gejala perilaku kekerasan $48 \%$, penurunan gejala halusinasi $47 \%$. Profile multimodal therapy direkomendasikan sebagai screening klien yang akan diberikan terapi spesialis dalam hal ini khususnya rational emotive behavior therapy.
\end{abstract}

Kata kunci: gejala haluasinasi; gejala perilaku kekerasan; kemampuan kognitif, afektif dan perilaku; profile multimodal therapy; rational emotive behavior therapy

Abstract

The Effectiveness of Rational Emotive Behavior Therapy Based on Profile Multimodal Therapy for Client's Schizophrenia with Violence and Hallucination Nursing Diagnoses at Mental Hospital. This study aims to determine the effectiveness of rational emotive behavior therapy (REBT) profile of multimodal therapy based on the client's ability and changes in symptoms violent behavior and hallucinations in Psychiatric Hospital. Quasi-experimental research design with a number of 56 respondents. 28 respondents had to get a Profile Multimodal Therapy REBT therapy as the intervention group, 28 respondents as a group of non intervention. The research found a decrease symptom of violent behavior and hallucinations bigger than not getting REBT based profile of multimodal therapy ( $p<0.05)$. Cognitive, affective and behavioral clients who get REBT based profile of multimodal therapy increased significantly ( $p<0.05$ ). Results clients experience an effectively improve cognitive, affective and behavioral to 57\% and reduction in symptoms of violent behavior $48 \%$, reduction in symptoms of hallucinations $47 \%$. Profile multimodal therapy is recommended as screening client will be given specialist treatment in this particular rational emotive behavior therapy

Keywords: cognitive, affective and behavioral; hallucination symptoms; profile multimodal therapy; rational emotive behavior therapy; symptoms of violent behavior

\section{Pendahuluan}

Skizofrenia merupakan salah satu jenis gangguan jiwa berat yang paling banyak ditemukan. Stuart (2009) menyebutkan di Amerika
Serikat sekitar 1 dari 100 orang mengalami skizofrenia. Departemen Kesehatan RI (2009) mencatat bahwa $70 \%$ gangguan jiwa terbesar di Indonesia adalah skizofrenia. Jumlah klien skizofrenia juga menempati $90 \%$ klien di ru- 
mah sakit jiwa di seluruh Indonesia (Jalil, 2006). Hasil Riset Kesehatan Dasar Nasional di Indonesia disebutkan bahwa prevalensi gangguan jiwa berat (Skizofrenia) adalah $4,6 \%$ dimana untuk jumlah yang tertinggi di propinsi DKI Jakarta yaitu 20,3\% sedangkan untuk wilayah propinsi Jawa Barat

mencapai 2,2\% (DepKes, 2008). Melihat banyaknya klien skizofrenia menjadi pemikiran perlunya meningkatkan pemahaman individu tentang gangguan jiwa berat yang satu ini, agar mampu memberikan penanganan yang tepat jika terjadi pada salah satu anggota keluarga maupun masyarakat.

Perilaku yang sering muncul pada klien skizofrenia menurut Keliat (2006) antara lain; motivasi kurang $(81 \%)$, isolasi sosial $(72 \%)$, perilaku makan dan tidur yang buruk (72\%), sukar menyelesaikan tugas (72\%), sukar mengatur keuangan $(72 \%)$, penampilan yang tidak rapi/bersih (64\%), lupa melakukan sesuatu $(64 \%)$, kurang perhatian pada orang lain (56\%), sering bertengkar (47\%), bicara pada diri sendiri (41\%), dan tidak teratur makan obat $(40 \%)$. Berdasarkan paparan diatas menunjukkan bahwa pada klien skizofrenia banyak ditemukan masalah yang memerlukan pemberian terapi yang mengacu pada konsep penyembuhan secara holistik, yang tidak hanya mengobati aspek psikis (kognisi, afeksi dan psikomotorik) dari klien namun juga memperhatikan aspek kesehatan fisik serta kualitas lingkungan hidup disekitar klien yang memengaruhi kehidupannya.

Lazarus (1992) menyatakan bahwa konsep penyembuhan penyakit didasarkan secara holistik yang tidak hanya mengobati aspek psikis (kognisi, afeksi dan psikomotor) dari klien saja namun juga memperhatikan tujuh aspek yang membentuk kepribadian dari manusia, yang meliputi perilaku (behaviour), perasaan (affect), pengindraan (sensation), angan-angan (imagery), pikiran (cognitition), hubungan interpersonal (interpersonal relationship) dan semua faktor-faktor yang berhu- bungan dengan keadaan biokimia dan fisiologis tubuh (drugs). Konsep penanganan holistik ini dalam psikoterapi kemudian disebut sebagai multimodal therapy.

Putri (2010) dalam penelitiannya terhadap 28 klien skizofrenia yang mengalami perilaku kekerasan menyatakan bahwa terapi Rational Emotive Behavior Therapy (REBT) mampu meningkatkan kemampuan kognitif sebesar $9,6 \%$ dan sosial $47 \%$. REBT juga mampu menurunkan respon emosi $43 \%$, fisiologis 76\%, dan perilaku 47\%. REBT dan CBT yang dilakukan secara bersama-sama pada klien yang memiliki lebih dari satu gejala menurut penelitian Lelono (2011) efektif menurunkan perilaku kekerasan sebesar $61 \%$, menurunkan tanda dan gejala munculnya halusinasi sebesar $52,1 \%$ dan menurunkan gejala harga diri rendah sebesar $66,2 \%$. Juga menunjukan hasil $74,53 \%$ untuk meningkatkan kemampuan kognitif, afektif dan perilaku pada klien perilaku kekerasan, halusinasi dan harga diri rendah. Hal ini juga didukung oleh penelitian dari Sudiatmika (2011) menunjukan hasil efektif menurunkan perilaku kekerasan hingga $77 \%$ dan penurunan gejala halusinasi mencapai $85 \%$. Untuk kemampuan kognitif meningkat $74 \%$, afektif $76 \%$ dan perilaku $77 \%$. Sedangkan hasil penelitian Hidayat (2011) menunjukan hasil mampu menurunkan gejala perilaku kekerasan yang terdiri atas kognitif, emosi, perilaku, sosial, fisiologi secara bermakna dari kategori sedang menjadi rendah dimana secara keseluruhan terjadi penurunan sebesar $44,45 \%$. Penelitian yang dilakukan para peneliti belum pernah menambahkan dengan profile multimodal therapy dimana penambahan PMT dapat menjadi lebih baik guna meningkatkan kemampuan klien selain menurunkan gejala perilaku.

\section{Metode}

Penelitian ini adalah penelitian quasi experimental dengan metode kuantitatif dengan menggunakan desain penelitian "Quasi Experimental Pre-Post Test with Control Group" dengan intervensi Rational Emotive 
Behavior Therapy (REBT) yang berdasarkan Profile Multimodal Therapy (REBT \& PMT) dan kontrol Rational Emotive Cognitive Behavior Therapy (RECBT). Teknik pengambilan sampel menggunakan Consecutive Sampling. Penelitian ini dilakukan untuk mengetahui efektivitas Rational Emotive Behavior Therapy berdasarkan profile multimodal therapy terhadap perubahan gejala dan kemampuan kognitif, afektif dan perilaku klien dengan perilaku kekerasan dan halusinasi yang dirawat di ruang rawat inap Rumah Sakit Jiwa.

Responden berjumlah 56 orang yang terdiri atas 28 orang menjadi kelompok kontrol dan 28 orang yang memiliki profile multimodal therapy sebagai kelompok intervensi. Analisis statistik yang digunakan adalah univariat, bivariat dengan analisis dependen dan independent sample t-Test, Chi-square dengan tampilan dalam bentuk tabel dan distribusi frekuensi.

\section{Hasil}

Karakteristik klien dengan perilaku kekerasan dan halusinasi dalam penelitian ini adalah pada kelompok intervensi jenis kelamin lebih banyak laki-laki 24 orang $(85,7 \%)$, jenjang pendidikan paling banyak adalah PT 11 orang $(39,4 \%)$ yang meliputi D3 9 orang dan S1 2 orang, pada pekerjaan lebih banyak yang tidak bekerja yaitu 16 orang $(57,1 \%)$, sebagian besar tidak kawin 15 orang $(53,6 \%)$. Sedangkan pada kelompok kontrol jenis kelamin lebih banyak laki-laki 19 orang $(67,9 \%)$, jenjang pendidikan paling banyak PT 12 orang (42,9\%) yang meliputi D3 10 orang S1 2 orang, lebih banyak yang bekerja 16 orang $(57,1 \%)$, untuk status perkawinan jumlah sama antara yang kawin dengan tidak kawin yaitu 14 orang $(50 \%)$

Pengaruh REBT berdasarkan profile multimodal therapy terhadap perubahan gejala pada perilaku kekerasan yang dibandingkan dengan hasil penelitian sebelumnya yaitu pemberian RECBT (Sudiatmika, 2011).

Hasil penelitian menunjukkan perubahan gejala perilaku kekerasan pada klien yang diberikan REBT berdasarkan profile multimodal therapy lebih baik dibandingkan dengan hasil penelitian sebelumnya yaitu pemberian RECBT. Uji statistik menunjukkan ada hubungan yang signifikan pemberian REBT berdasarkan PMT dibandingkan dengan RECBT $(\mathrm{p}=0,000)$.

Pengaruh REBT berdasarkan profile multimodal therapy terhadap perubahan gejala pada halusinasi yang dibandingkan dengan hasil penelitian sebelumnya yaitu pemberian RECBT (Sudiatmika, 2011).

Tabel 1. Perubahan gejala perilaku kekerasan klien yang diberikan REBT \& PMT dengan RECBT

\begin{tabular}{|c|c|c|c|c|c|c|c|c|}
\hline \multirow{3}{*}{ Gejala } & \multirow{3}{*}{ Kelompok } & \multicolumn{3}{|c|}{ REBT \& PMT $(\mathrm{N}=56)$} & \multicolumn{3}{|c|}{ RECBT $(\mathrm{N}=60)$} & \multirow{3}{*}{$\mathbf{p}$} \\
\hline & & & Mear & & & Mean & & \\
\hline & & Sblm & Ssdh & Slsih & Sblm & Ssdh & Slsih & \\
\hline \multirow[t]{2}{*}{ Kognitif } & Intervensi & 15,25 & 10,29 & 4,96 & 13,87 & 10,53 & 3,34 & 0,000 \\
\hline & Kontrol & 15,64 & 12,36 & 3,28 & 14,40 & 12,30 & 2,10 & 0,000 \\
\hline \multirow[t]{2}{*}{ Emosi } & Intervensi & 18,68 & 11,25 & 7,43 & 15,83 & 10,77 & 5,06 & 0,000 \\
\hline & Kontrol & 18,68 & 15,00 & 3,68 & 14,97 & 13,00 & 1,97 & 0,000 \\
\hline \multirow[t]{2}{*}{ Perilaku } & Intervensi & 16,00 & 10,36 & 5,64 & 13,73 & 10,20 & 3,53 & 0,000 \\
\hline & Kontrol & 15,82 & 13,36 & 2,46 & 14,47 & 12,50 & 1,97 & 0,000 \\
\hline \multirow[t]{2}{*}{ Sosial } & Intervensi & 19,46 & 12,68 & 6,78 & 19,37 & 12,73 & 6,63 & 0,000 \\
\hline & Kontrol & 18,89 & 15,36 & 3,53 & 18,60 & 14,77 & 3,83 & 0,000 \\
\hline \multirow[t]{2}{*}{ Fisiologis } & Intervensi & 8,46 & 5,21 & 3,25 & 8,70 & 5,77 & 2,93 & 0,000 \\
\hline & Kontrol & 8,54 & 6,96 & 1,58 & 8,53 & 6,47 & 1,06 & 0,000 \\
\hline \multirow[t]{2}{*}{ PK } & Intervensi & 77,86 & 49,79 & 28,07 & 71,50 & 50,00 & 21,50 & 0,000 \\
\hline & Kontrol & 77,57 & 63,04 & 14,53 & 70,97 & 59,03 & 11,93 & 0,000 \\
\hline
\end{tabular}


Tabel 2. Perubahan gejala halusinasi klien yang diberikan REBT \& PMT dengan RECBT

\begin{tabular}{|c|c|c|c|c|c|c|c|c|}
\hline \multirow{3}{*}{ Gejala } & \multirow{3}{*}{ Kelompok } & \multicolumn{3}{|c|}{ REBT \& PMT $(\mathrm{N}=56)$} & \multicolumn{3}{|c|}{ RECBT $(N=60)$} & \multirow{3}{*}{$\mathbf{p}$} \\
\hline & & \multicolumn{3}{|c|}{ Mean } & \multicolumn{3}{|c|}{ Mean } & \\
\hline & & Sblm & Ssdh & Slsih & Sblm & Ssdh & Slsih & \\
\hline \multirow[t]{2}{*}{ Kognitif } & Intervensi & 8,25 & 5,07 & 3,18 & 7,60 & 4,20 & 3,40 & 0,000 \\
\hline & Kontrol & 8,14 & 6,39 & 1,75 & 6,83 & 5,47 & 1,37 & 0,000 \\
\hline \multirow[t]{2}{*}{ Emosi } & Intervensi & 8,29 & 4,18 & 4,11 & 7,83 & 4,57 & 3,26 & 0,000 \\
\hline & Kontrol & 7,96 & 5,75 & 2,21 & 6,90 & 5,47 & 1,43 & 0,000 \\
\hline \multirow[t]{2}{*}{ Perilaku } & Intervensi & 7,79 & 4,79 & 3,00 & 7,00 & 4,33 & 2,67 & 0,000 \\
\hline & Kontrol & 7,57 & 5,86 & 1,71 & 6,43 & 5,57 & 0,86 & 0,000 \\
\hline \multirow[t]{2}{*}{ Sosial } & Intervensi & 7,93 & 4,00 & 3,39 & 7,50 & 4,13 & 3,37 & 0,000 \\
\hline & Kontrol & 7,64 & 5,57 & 2,07 & 6,97 & 5,63 & 1,33 & 0,000 \\
\hline \multirow[t]{2}{*}{ Fisiologis } & Intervensi & 8,39 & 5,71 & 2,68 & 7,97 & 5,90 & 2,07 & 0,000 \\
\hline & Kontrol & 8,50 & 7,25 & 1,25 & 7,47 & 6,90 & 0,57 & 0,000 \\
\hline \multirow[t]{2}{*}{ Halusinasi } & Intervensi & 40,64 & 23,75 & 16,89 & 37,90 & 23,13 & 14,77 & 0,000 \\
\hline & Kontrol & 39,82 & 30,82 & 9,00 & 34,60 & 29,03 & 5,57 & 0,000 \\
\hline
\end{tabular}

Hasil penelitian menunjukkan perubahan gejala halusinasi pada klien yang diberikan REBT berdasarkan profile multimodal therapy lebih baik dibandingkan dengan hasil penelitian sebelumnya yaitu pemberian RECBT. Hanya gejala kognitif pada klien yang mendapatkan RECBT lebih baik dibandingkan dengan pemberian REBT dan PMT. Uji statistik menunjukkan ada hubungan yang signifikan pemberian REBT berdasarkan PMT dibandingkan dengan RECBT $(\mathrm{p}=0,000)$.

Perubahan kemampuan kognitif, afektif dan perilaku pada klien skizofrenia dengan maslah keperawatan perilaku kekerasan dan halusinasi setelah diberikan REBT berdasarkan profile multimodal therapy.

Perubahan Kognitif. Pada penelitian ini pemberian REBT dan PMT mampu mening-katkan kemampuan kognitif dari 23,32 menjadi 41,07 sedangkan pemberian RECBT meningkatkan kemampuan kognitif ddari 33,63 menjadi 65,87 (lihat Gambar 3).

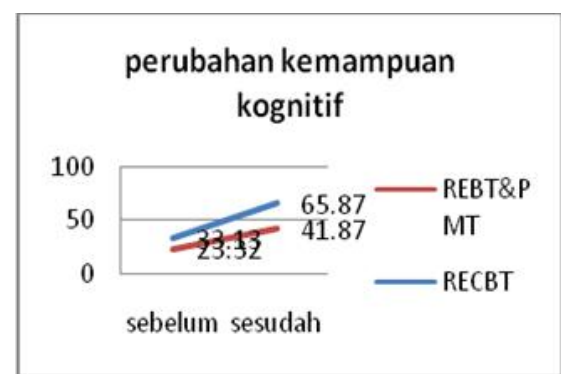

Gambar 3. Perubahan kemampuan kognitif
Perubahan Afektif. Pada penelitian ini pemberian REBT dan PMT mampu meningkatkan kemampuan afektif dari 17,14 menjadi 29,93 sedangkan pemberian RECBT meningkatkan kemampuan afektif dari 33,13 menjadi 66,03 (lihat Gambar 4).

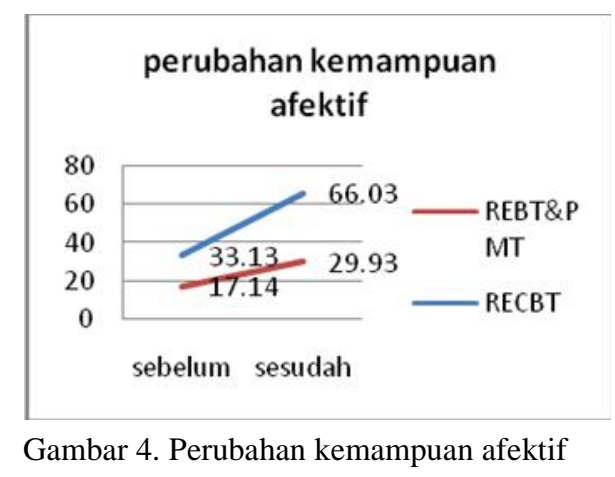

Perubahan Perilaku. Pada penelitian ini pemberian REBT dan PMT mampu mening-katkan kemampuan perilaku dari 22,32 menjadi 37,32 sedangkan pemberian RECBT meningkatkan kemampuan perilaku dari 33,87 menjadi 66,90 (lihat Gambar 5).

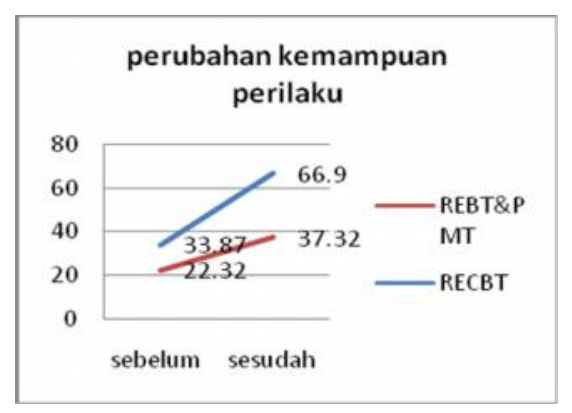

Gambar 5. Perubahan kemampuan perilaku 
Efektifitas Terapi REBT berdasarkan Profile Multimodal Therapy terhadap peningkatan kemampuan kognitif, afektif, dan perilaku REBT pada klien skizofrenia dengan masalah keperawatan perilaku kekerasan dan halusinasi dengan dibandingkan hasil penelitian terdahulu dapat dilihat efektivitas terapi REBT berdasarkan profile multimodal therapy dalam meningkatkan kemampuan kognitif, afektif dan perilaku sebesar $57 \%$. Sedangkan penelitian sebelumnya (Sudiatmika, 2011) RECBT memberikan hasil dapat meningkatkan kemampuan kognitif, afektif dan perilaku sebesar $41 \%$.

\section{Pembahasan}

Efektifitas Terapi REBT berdasarkan Profile Multimodal Therapy untuk menurunkan gejala perilaku kekerasan sebesar $48 \%$ sedangkan yang diberikan RECBT mampu menurunkan gejala perilaku kekerasan sebesar $45 \%$. Hal ini menunjukan bahwa klien dengan perilaku kekerasan dan halusinasi jika diberikan terapi REBT akan lebih baik yang dengan profile multimodal therapy dengan RECBT meskipun hampir sama nilainya

Jensen (2008) yang menyatakan bahwa respon-respon perilaku kekerasan mengalami perubahan yang bermakna disebabkan karena terapi REBT yang diberikan menggunakan pendekatan kognitif dan perilaku dengan mengemukakan fakta-fakta bahwa perilaku yang dihasilkan bukan berasal dari kejadian yang dialami namun dari keyakinan-keyakinan yang tidak rasional. REBT diberikan bertujuan untuk mengurangi keyakinan irrasional dan menguatkan keyakinan rasional yang dapat efektif untuk dewasa yang marah dan agresif (Ellis, 1997; Ellis, 2003).

REBT juga merupakan bagian dari pilihan terapi dalam Multimodal Therapy yang diberikan dengan memperhatikan tujuh aspek pembentukan kepribadian seseorang (Lazarus, 1992). Multimodal Therapy melihat bahwa manusia merupakan satu kesatuan yang unik oleh karenanya jika adanya gangguan pada sa- lah satu aspek akan memengaruhi aspek yang lain (Lazarus, 1992). REBT menjadi salah satu pilihan terapi pada klien yang mengalami gangguan karena kebanyakan orang di saat sedang ada masalah perilaku yang muncul cenderung menghindari atau mengalihkan obyek yang menimbulkan masalah, perasaan khawatir dan kegelisahan terus menerus, rasa bersalah dan konsep diri yang bruruk yang disertai dengan keyakinan-keyakinan yang salah atau tidak rasional, sehingga dengan diberikan terapi yang mengajarkan pada klien untuk mengenali peristiwa yang rasional dan tidak rasional diharapkan klien akan dapat mengatasi masalah yang muncul.

Efektifitas Terapi REBT berdasarkan Profile Multimodal Therapy untuk menurunkan gejala halusinasi dengan dibandingkan hasil penelitian terdahulu dapat dilihat bahwa efektivitas terapi REBT berdasarkan profile multimodal therapy dalam menurunkan halusinasi sebesar 47\%. Sedangkan penelitian yang dilakukan oleh Sudiatmika (2011) bahwa RECBT menurunkan tanda gejala halusinasi sebesar $62 \%$.

Kondisi perpecahan pada pikiran, terutama pada persepsi klien yang mengalami skizofrenia sering dikaitkan dengan halusinasi. Hal ini diperkuat pendapat Stuart dan Laraia (2005); Stuart (2009); Townsend (2009); Fontaine (2009) ketika terjadi perubahan persepsi pada klien skizofrenia, bersamaan gangguan dalam fungsi kognitif secara umum, ditemukan bahwa 90\% klien mengalami halusinasi dan delusi dimana halusinasi pendengaran dialami 50-80\% klien dengan skizofrenia. Halusinasi merupakan perubahan dalam jumlah dan pola stimulus yang diterima disertai dengan penurunan berlebih distorsi atau kerusakan respon beberapa stimulus NANDA-I (2009-2011). Klien dengan skizofrenia yang mengalami halusinasi akibat kesalahan persepsinya sering kehilangan kontrol dan mengikuti perintah dari halusinasinya yang mengakibatkan klien berperilaku di luar kendali dan melakukan perilaku kekerasan. 
Penggunaan terapi REBT mempunyai target dimana bahwa pada dasarnya pola pemikiran manusia terbentuk melalui serangkaian proses stimulus-kognitif-respon. Peneliti sebagai terapis diharapkan mampu berfungsi sebagai guru/tranier dan mengajarkan kepada klien strategi pembelajaran dalam perubahan kognitif yang berdampak pada afektif dan perilaku yang adaptif. Sedangkan halusinasi merupakan salah satu gejala positif pada klien skizofrenia yang merupakan suatu penyakit yang memengaruhi otak yang menyebabkan timbulnya fikiran, persepsi, emosi, gerakan dan perilaku yang aneh dan terganggu (Videbeck, 2006; 2008). Sehingga dapat dinyatakan bahwa skizofrenia sebagai penyakit mental serius yang memengaruhi otak dengan ciri adanya perpecahan antara pikiran, emosi dan perilaku sehingga klien menunjukan perilaku aneh yang dianggap tidak sesuai dengan standar di masyarakat.

Multimodal Therapy terhadap peningkatan kemampuan kognitif, afektif dan perilaku REBT pada klien skizofrenia dengan masalah keperawatan perilaku kekerasan dan halusinasi dengan dibandingkan hasil penelitian terdahulu dapat dilihat efektivitas terapi REBT berdasarkan profile multimodal therapy dalam meningkatkan kemampuan kognitif, afektif dan perilaku sebesar $57 \%$. Sedangkan, penelitian sebelumnya (Sudiatmika, 2011) RECBT memberikan hasil dapat meningkatkan kemampuan kognitif, afektif dan perilaku sebesar $41 \%$.

Hasil di atas dapat terjadi karena pada klien skizofrenia dengan perilaku kekerasan dan halusinasi terjadi masalah berupa gangguan pada pengontrolan perilaku yang dapat mencederai diri maupun orang lain. Perilaku yang muncul pada skizofrenia dengan perilaku kekerasan berupa agresif dan hostile. Menurut Stuart dan Laraia (2005; Stuart, 2009; Townsend, 2005; Townsend, 2009; Fontaine, 2009) ketika terjadi perubahan persepsi pada klien skizofrenia, bersamaan gangguan dalam fungsi kognitif secara umum, ditemukan bah- wa $90 \%$ klien mengalami halusinasi dan delusi dimana halusinasi pendengaran dialami 50-80\% klien dengan skizofrenia. Klien dengan skizofrenia yang mengalami halusinasi akibat kesalahan persepsinya sering kehilangan kontrol dan mengikuti perintah dari halusinasinya yang mengakibatkan klien berperilaku di luar kendali dan melakukan perilaku kekerasan. Perilaku ini terjadi disebabkan karena klien merasakan adanya ancaman yang dipersepsikan menganggu konsep diri dan integritas diri.

Pemberian REBT, klien dilatih untuk bisa mengenali pikiran atau persepsi yang salah atau distorsi kognitif dari kejadian yang dirasakan yang mengancam atau juga bisa dari penyebab perilaku kekerasan, malu dan rendah diri yang dialami serta apa yang klien rasakan dari suara-suara yang muncul, kemudian klien diarahkan untuk bisa menilai akibat dari kejadian tadi yang berdampak pada perasaan dengan mengukur menggunakan termometer perasaan dan dampak terhadap perilaku berupa perilaku maladaptif yang sering muncul. Kejadian atau peristiwa itu klien diajarkan untuk menilai kejadian berdasarkan keyakinan klien anggap tepat, namun keyakinan klien sering sering berupa keyakinan yang tidak nyata atau berdasar opini bukan fakta-fakta yang ada, maka klien dilatih untuk melawan opini-opini yang tidak nyata tadi dengan faktafakta yang nyata hingga klien mulai mengatasi distorsi kognitifnya dan dapat berpikir rasional, dimana berdampak pada perasaan nyaman, tenang, berharga, dibutuhkan, merasa terlindungi dan perilaku yang asertif, tidak menyendiri, dan lainnya.

Profile Multimodal Therapy yang dimiliki klien juga dapat memberikan pengaruh terhadap keberhasilan REBT meningkatkan kemampuan secara kognitif, afektif dan psikomotor dari klien dikarenakan dalam menetapkan terapi berdasarkan hasil analisis dari tujuh aspek yang dimiliki klien yang dalam hal ini adalah pada behaviour, affect, sensation, imagery, cognition, interpersonal 
relationship and drugs yang hal tersbut berada pada diri seseorang yang merupakan satu kesatuan yang unik oleh karenanya adanya gangguan pada salah satu modalitas diatas akan mempengaruhi modalitas yang lainnya (Lazarus,1992; Dryden, David, \& Ellis, 2010).

Berdasarkan paparan di atas penggunaan terapi REBT mempunyai target yang berdasar pada konsep bahwa emosi dan perilaku merupakan hasil dari proses pikir yang memungkinkan bagi manusia untuk memodifikasinya seperti proses untuk mencapai cara yang berbeda dalam merasakan dan bertindak (Froggatt, 2005). Reaksi emosional seseorang sebagian besar disebabkan oleh evaluasi, interpretasi, dan filosofi yang disadari maupun tidak disadari. Hambatan psikologis atau emosional tersebut merupakan akibat dari cara berpikir yang tidak logis dan irrasional, dimana emosi yang menyertai individu dalam berpikir penuh dengan prasangka, sangat personal dan irrasional. Menurut Ellis (2003), manusia pada dasarnya adalah unik yang memiliki kecenderungan untuk berpikir rasional dan irrasional. Ketika berpikir dan bertingkah laku rasional manusia akan efektif, bahagia, dan memiliki kemampuan.

\section{Kesimpulan}

Karakterisitik dari 56 orang klien yang menjadi responden yang dilakukan dalam penelitian ini rata-rata berusia 33,21 tahun dengan usia termuda 18 tahun dan tertua 55 tahun, jenis kelamin lebih banyak laki-laki, status pekerjaan adalah yang tidak bekerja, status pendidikan paling banyak di jenjang Perguruan Tinggi, status perkawinan sebagian besar tidak kawin, frekuensi dirawat di rumah sakit rata-rata 2 kali. Hasil screening dari 56 klien yang menjadi responden hanya 28 orang yang dapat diberikan REBT berdasarkan profile multimodal therapy. Rational emotive behaviour therapy berdasarkan profile multimodal therapy efektif menurunkan gejala perilaku kekerasan dan gejala halusinasi (kognitif, emosi, perilaku, sosial, dan fisiologis) dari tingkat sedang ke rendah. Rational emotive behaviour therapy berdasarkan profile multimodal therapy efektif meningkatkan kemampuan klien yaitu kognitif, afektif dan perilaku dari tingkat rendah ke tingkat tinggi.

Perawat jiwa di rumah sakit diharapkan dapat melakukan screning klien dengan profile multimodal therapy guna menentukan indikasi pemberian terapi terutama terapi keperawatan spesialis dan selalu memotivasi klien serta mengevaluasi kemampuan-kemampuan yang telah dipelajari dan dimiliki oleh klien sehingga latihan yang diberikan membudaya. Apabila terjadi kemunduran pada klien hendaknya perawat mengkonsultasikan perkembangan kliennya yang telah mendapat terapi spesialis kepada perawat spesialis yang dimiliki rumah sakit. Hasil penelitian ini dapat digunakan sebagai evidence based pengembangan profile multimodal therapy guna penentuan indikasi pemberian terapi REBT baik pada individu maupun kelompok. Perlu penelitian lanjut tentang pengaruh profile multimodal therapy dengan terapi spesialis lainnya; pengaruh peningkatan kemampuan klien setelah terapi REBT terhadap penurunan gejala perilaku kekerasan dan halusinasi pada klien skizofrenia (BA, INR, MK).

\section{Referensi}

Departemen Kesehatan Republik Indonesia. (2008). Riset kesehatan dasar 2007. http://www.litbang.depkes.go.id/LaporanRKD/ IndonesiaNasional.pdf.

Dryden, W., David, D., \& Ellis, A. (2010). Rational emotive behaviour therapy: Handbook of Cognitive-behavioral therapies (3rd ed). New York, US: Guilford Press.

Ellis, A. (1997). REBT and its application to Group Therapy, In Special Applications of REBT: A. therapit's casebook, Yankura, J., and Dryden, W. (eds). New York: Springer Publishing Company. pp 131-161. 
Ellis, A. (2003). Reasons why rational emotive behaviour therapy is relatively neglected in the professional and scientific literature. Journal of Rational Emotive \& cognitive - behaviour therapy, 21 (3/4), 245-252.

Ellis, A. (2004). Why rational emotive behaviour therapy is the most comprehensive and effective from of behaviour therapy. Journal of Rational emotive behaviour therapy, 22 (2), 85-92.

Fontaine, K.L. (2009). Mental health nursing (7th Ed.). New Jersey: Pearson Education, Inc.

Froggatt, W. (2005). A brief introduction to rational emotive behaviour therapy (3rd Ed.). Diperoleh dari www.rational.org.nz/profdocs/Intro-REBT.pdf.

Hidayat, E. (2011). Pengaruh cognitive behaviour therapy dan rational emotive behaviour therapy pada perilaku kekerasan dan harga diri rendah di Rumah Sakit Marzoeki Mahdi Bogor (Tesis, Tidak dipublikasikan). Fakultas Ilmu Keperawatan Universitas Indonesia, Jakarta.

Jalil, M. (2006). Faktor-faktor yang mempengaruhi kekambuhan penderita skizoprenia di RSJ Prof. Dr. Soeroyo Magelang. (Skripsi. Tidak dipublikasikan)

Jensen. (2010). Evaluating the ABC models of rational emotive behaviour therapy theory: An analysis of the relationship between irrational thinking and guilt (Thesis of Science in Psychology). The Faculty of Department Psychology Villanova University, United State. ProQuest LLC.

Keliat, B.A. (2006). Peran serta keluarga dalam perawatan klien gangguan jiwa. Jakarta: EGC.

Lazarus, A.A. (1992). Multimodal therapy: Technical eclecticism with minimal integration. New York: Basic Books.

Lelono, S.K. (2011). Efektifitas cognitive behaviour therapy dan rational emotive behaviour therapy terhadap klien perilaku kekerasan, halusinasi dan harga diri rendah di
RSMM Bogor (Tesis, Tidak dipublikasikan). Fakultas Ilmu Keperawatan Universitas Indonesia, Jakarta.

NANDA. (2009). Nursing diagnoses: Definitions \& classification 2009-2011. Philadelphia: NANDA International.

Putri, D.W. (2010) Pengaruh rational emotive behaviour therapy (REBT) terhadap klien perilaku kekerasan di Rumah Sakit Marzoeki Mahdi Bogor (Tesis, Tidak dipublikasikan). Fakultas Ilmu Keperawatan Universitas Indonesia, Jakarta.

Sudiatmika, I.K. (2011). Pengaruh cognitive behaviour therapy dan rational emotive behaviour therapy pada perilaku kekerasan dan halusinasi di Rumah Sakit Marzoeki Mahdi Bogor (Tesis, Tidak dipublikasikan). Fakultas Ilmu Keperawatan Universitas Indonesia, Jakarta.

Stuart, G.W., \& Laraia, M.T. (2005). Principles and practice of psychiatric nursing (8th Ed.). Missouri: Mosby, Inc.

Stuart, G.W. (2009). Principles and practice of psychiatric nursing (9th Ed.). Missouri: Mosby, Inc.

Townsend, M.C. (2005). Essentials of psychiatric mental health nursing (3rd Ed.). Philadelphia: F.A. Davis Company.

Townsend, M.C. (2009). Psychiatric mental health nursing concepts of care in evidence-based practice (6th Ed.). Philadelphia: F.A. Davis Company.

Videbeck, S.L. (2006). Psychiatric-mental health nursing (4th Ed.). Philadelphia: Lippincott Williams \& Wilkins.

Videbeck, S.L. (2008). Buku ajar keperawatan jiwa. Jakarta: EGC. 